\title{
IMPLEMENTASI PREDIKSI PENJUALAN OBAT MENGGUNAKAN METODE LEAST SQUARE PADA APOTEK DEMAK FARMA JAYA
}

\author{
Indah Rahmawati ${ }^{{ }^{*}}$, Rony Wijanarko ${ }^{2}$ \\ ${ }^{1,2}$ Jurusan TEKNIK INFORMATIKA , Fakultas TEKNIK, Universitas Wahid Hasyim \\ Jl. Menoreh Tengah X/22, Sampangan, Semarang 50236. \\ *Email: indahrahmawati994@gmail.com
}

\begin{abstract}
Abstrak
Apotek Demak Farma Jaya merupakan pelayanan penjualan obat yang beralamat di Jalan Bhayangkara Baru nomor 09 Demak. Penjualan setiap minggunya mengalami naik turun, akibatnya tidak jarang akan kehabisan persediaan obat dan persediaan menjadi tidak dinamis. Selain itu terdapat permasalahan dalam hal merekap data laporan setiap minggunya masih manual yaitu menggunakan buku dan alat tulis. Oleh karena itu perlu ada suatu sistem prediksi yang dapat memprediksi penjualan setiap minggunya. Metode yang digunakan yaitu metode least square, bahasa pemrograman yang digunakan dalam sistem prediksi yang dihasilkan yaitu PHP. Berdasarkan hasil uji coba dapat disimpulkan sistem prediksi penjualan obat dapat memperkirakan penjualan pada minggu yang akan datang menggunakan metode least square untuk memprediksi penjualan obat di Apotek dengan tingkat kesalahan terkecil.
\end{abstract}

Kata kunci: prediksi, penjualan, Least Square, PHP

\section{PENDAHULUAN}

Zaman sekarang merupakan zaman moderen yang banyak memanfaatkan kecanggihan teknologi komputer, banyak perusahaan, lembaga pendidikan ataupun lembaga sosial yang merubah sistem manual yang telah ada dan telah dijalankan sejak lama dengan sistem baru yang memanfaatkan kecanggihan teknologi komputer.

Dengan melihat kemajuan teknologi komputer terkini, maka dari pihak Apotek Demak Farma Jaya berkeinginan mengubah suatu sistem manual menjadi sistem komputerisasi dengan teknologi web di bidang perkiraan penjualan obat-obatan. Dengan membuat suatu sistem komputerisasi ini diharapkan proses perkiraan penjualan yang akan dilakukan dapat menghasilkan suatu keputusan yang efesien, efektif, serta akurat. Adapun maksud dari pembuatan sistem untuk perkirakan penjualan obat-obatan pada Apotek Demak Farma Jaya adalah untuk mendapatkan suatu keputusan tentang penjualan obat-obatan yang ada, sehingga diharapkan pihak managemen dapat mengambil suatu tindakan yang akan dilakukan nantinya di dalam proses penjualan yang akan datang.

\section{TINJAUAN PUSTAKA}

Pamungkas (2016) dalam penelitiannya Implementasi Metode Least Square Untuk Prediksi Penjualan Tahu Pong. Penelitian ini membahas penggunaan metode least square untuk melakukan perkiraan terhadap penjualan tahu pong. Adapun data yang digunakan untuk prediksi yaitu hasil penjualan mulai dari tanggal 1 April 2016 sampai dengan 31 Mei 2016. Periode yang diprediksi adalah satu hari berikutnya karena proses produksi dan pengadaan tahu pong setiap hari dilakukan. Sistem yang dibuat berbasis desktop menggunakan bahasa pemrograman $\mathrm{C \#}$ dan menggunakan database MySql.

Zuhriyanto (2016) membuat Analisa Rentet Waktu pada Data Donor Darah dan Kebutuhan Darah Menggunakan Algoritma Linear Regression dan Metode Least Square. Penelitian ini menerapkan algoritma linear regression dan least square yang berfungsi untuk mengolah data rentet waktu pendonor dan distribusi darah di PMI kota Yogyakarta. Dengan menggunakan kedua algoritma tersebut untuk melakukan prediksi permintaan darah, dan terbukti bahwa algoritma linear regression lebih baik penerapannya dibandingkan metode least square. Dikarenakan hasil prediksi dan pengujian menunjukan penggunaan algoritma linear regression memiliki residual error yang lebih sedikit 339.1 sedangkan algoritma least square memiliki tingkat residual error 564.3 dengan demikian algoritma linear regression lebih cocok digunakan untuk data pendonor dan distribusi darah. Sistem aplikasi 
yang dibuat berbasis desktop menggunakan VB.Net dan database Sql Server.

\subsection{Implementasi}

Implementasi adalah kegiatan yang dilakukan untuk menguji data dan menerapkan sistem yang diperoleh dari kegiatan seleksi. Implementasi merupakan salah satu unsur pertahapan dari keseluruhan pembangunan sistem komputerisasi, dan unsur yang harus dipertimbangkan dalam pembangunan sistem komputerisasi yaitu masalah perangkat lunak (software), karena perangkat lunak yang digunakan haruslah sesuai dengan masalah yang akan diselesaikan, disamping masalah perangkat keras (hardware) itu sendiri (Kadir, 2009).

\subsection{Prediksi (Peramalan)}

Peramalan penjualan adalah perkiraan penjualan pada waktu yang akan datang dalam keadaan tertentu dan dibuat berdsarkan datadata yang pernah terjadi dan atau mungkin akan terjadi (Nafarin, 2000).

\subsection{Penjualan}

Penjualan adalah pendapatan lazim dalam perusahaan dan merupakan jumlah kotor yang dibebankan kepada pelanggan atas barang dan jasa (Simamora, 2000), sedangkan pengertian penjualan menurut Chairul Marom menyatakan bahwa Penjualan artinya penjualan barang dagangan sebagai usaha pokok perusahaan yang biasanya dilakukan secara teratur. (Marom, 2002).

\subsection{Metode Least Square}

Metode Least Square merupakan metode yang diperoleh dengan cara menentukan persamaan garis yang mempunyai jumlah terkecil dari kuadrat selisih data asli dengan data pada garis trend. Metode kuadrat terkecil ini yang paling banyak digunakan dalam analisis deret berskala untuk peramalan bisnis. Rumus penghitungannya : $\mathrm{Y}=\mathrm{a}+\mathrm{bx} \mathrm{b}=$ $n \sum X Y-\sum X Y n \sum X 2-\left(\sum X\right)^{2} \mathrm{a}=\sum Y n-\mathrm{b} \sum X n$ Dalam hal ini $Y^{\prime}=$ adalah nilai dari ramalan dengan trend. $13 \mathrm{a}=$ nilai tetap (konstanta) atau nilai $Y^{\prime}$ pada $\mathrm{X}$ sama dengan nol. $\mathrm{b}=$ kemiringan (slope) atau perubahan nilai $\mathrm{Y}$ dari waktu ke waktu. $\mathrm{x}=$ periode waktu ke waktu (Narafin, 2013).

\section{METODE PENGEMBANGAN SISTEM}

\subsection{Classical Life Cycle}

Metode pengembangan sistem yang dipakai adalah SDLC model iteratif. Kerangka pikir penelitian ini ditunjukkan pada gambar 1 .

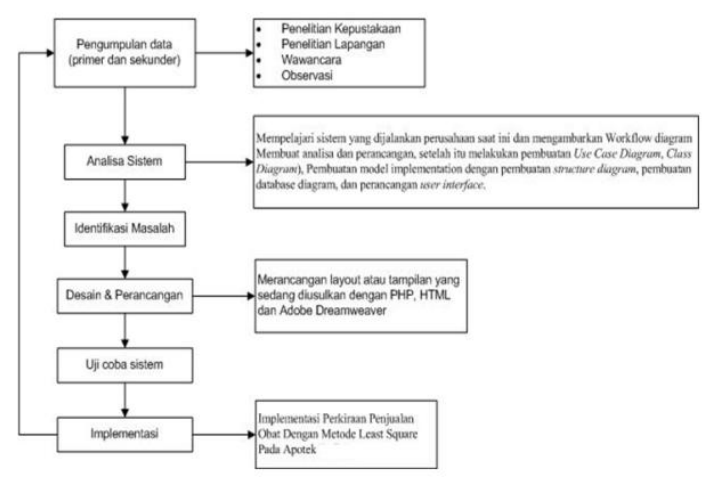

Gambar 1. Kerangka pikir penelitian

\subsection{Perancangan Sistem}

\section{Use Case Diagram Sistem Perkiraan Penjualan}
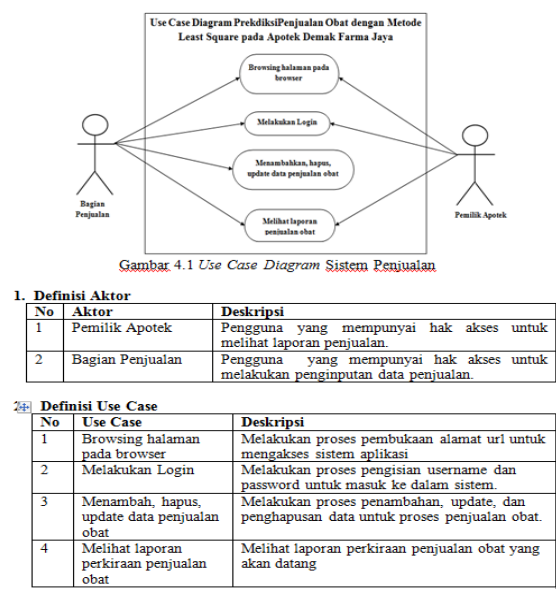

Gambar 2. Diagram Use Case

\section{Perancangan User Interface Sistem Prediksi Penjualan}

a. User Interface Halaman Login

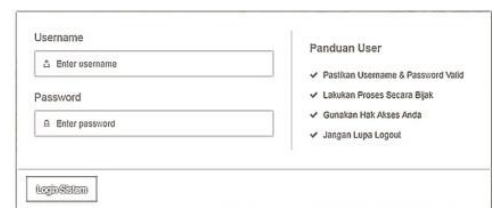

Gambar 3. User Interface Halaman Login

b. User Interface Halaman Tambah Data Barang 


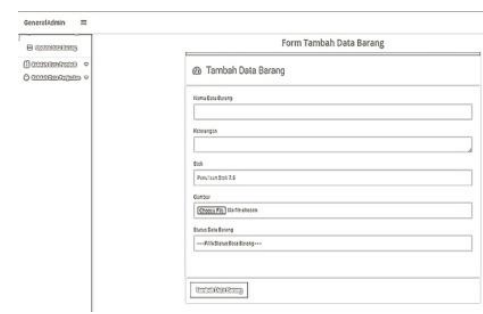

Gambar 4. User Interface Halaman Tambah Data Barang

c. User Interface Halaman Update Data Barang

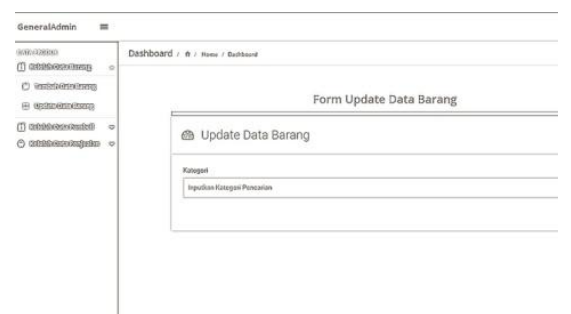

Gambar 5. User Interface Halaman Update Data Barang

d. User Interface Halaman Tambah Data Penjualan

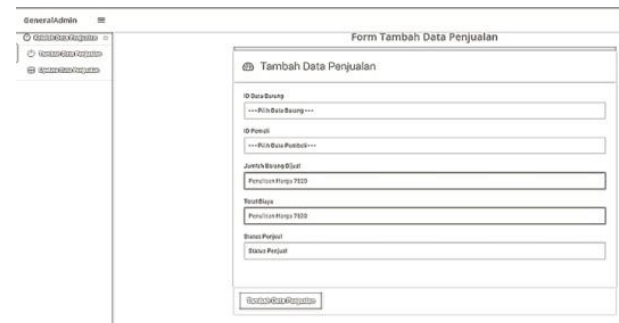

Gambar 6. User Interface Halaman Tambah Data Penjualan

e. User Interface Halaman Update Data Penjualan

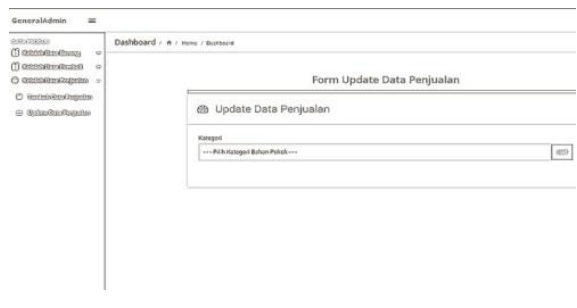

Gambar 7. User Interface Halaman Update Data Penjualan

f. User Interface Halaman Laporan Perkiraan Penjualan

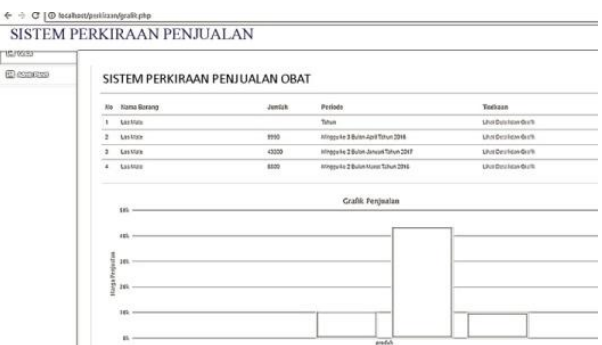

Gambar 8. User Interface Halaman Laporan Perkiraan Penjualan

HASIL DAN PEMBAHASAN

5.1 Halaman Login

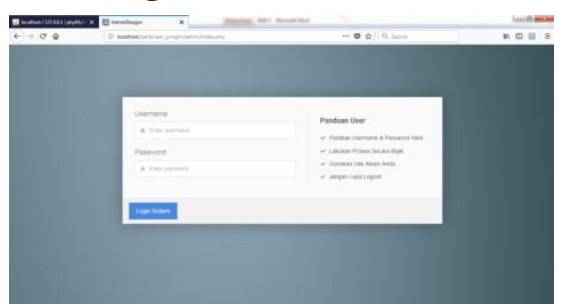

Gambar 9. Halaman Login

\subsection{Halaman Tambah Data Barang}

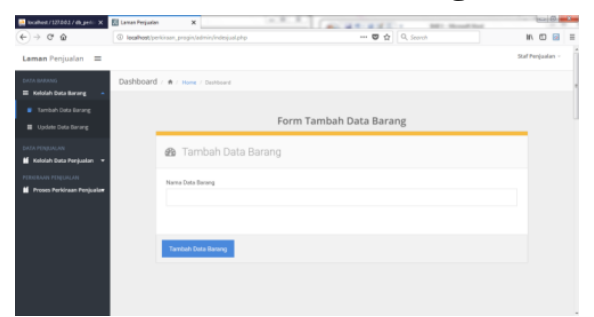

Gambar 10. Halaman Tambah Data Barang

\subsection{Halaman Update Data Barang}

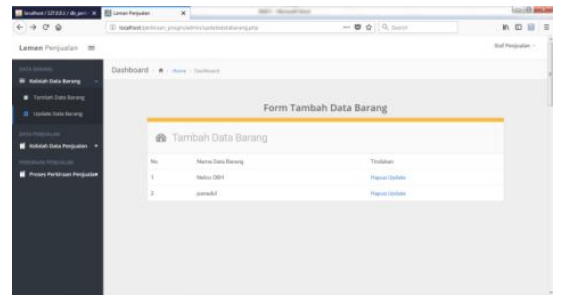

Gambar 11. Halaman Update Data Barang

\subsection{Halaman Tambah Data Penjualan}

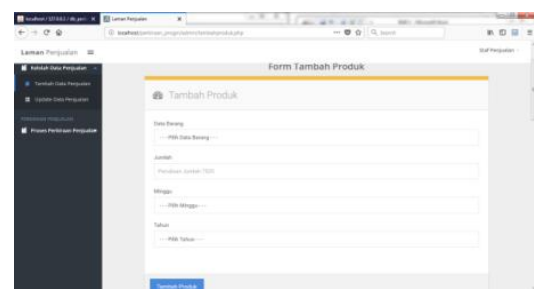

Gambar 12. Halaman Tambah Data Penjualan 


\subsection{Halaman Grafik Penjualan}

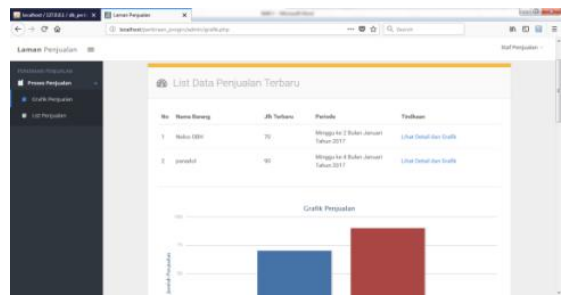

Gambar 13. Halaman Grafik Penjualan

\subsection{Halaman Perkiraan Data Penjualan}

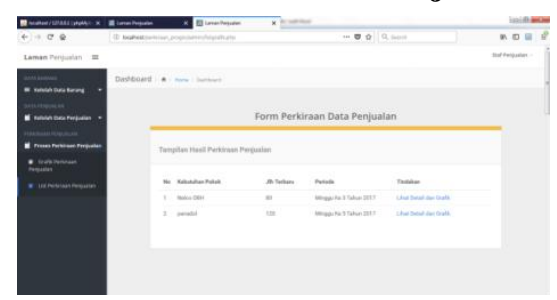

Gambar 14. Halaman Perkiraan Data Perkiraan

\subsection{Halaman Hasil Penjualan}

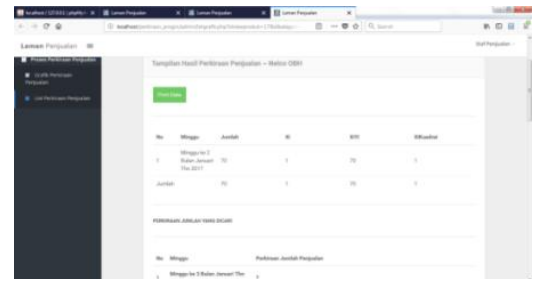

Gambar 15. Halaman Hasil Penjualan

\subsection{Halaman Perhitungan Penjualan}

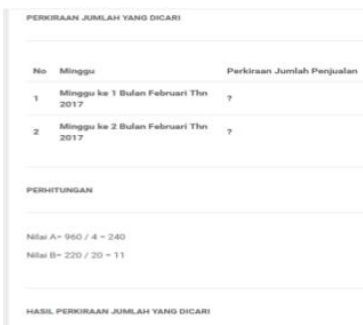

Gambar 16. Halaman Perhitungan

Gambar 17 merupakan hasil dari perhitungan.

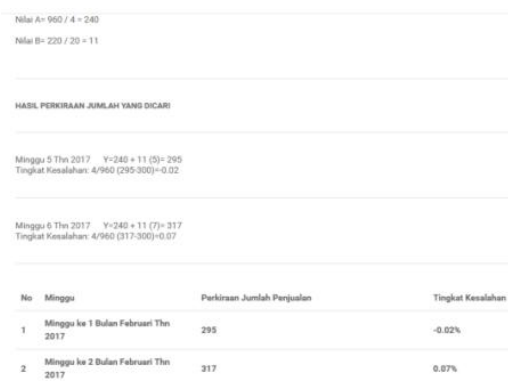

Gambar 17. Hasil Perhitungan
Dari gambar 17. maka dapat dihitung dengan metode least square seperti yang ditunjukkan pada tabel 1 .

Tabel 1. Perhitungan dengan metode least square

\begin{tabular}{ccccc} 
Minggu & Jumlah & Xi & XiYi & XiKuadrat \\
\hline 1 & 200 & -3 & -600 & 9 \\
2 & 245 & -1 & -245 & 1 \\
3 & 240 & 1 & 240 & 1 \\
4 & 275 & 3 & 825 & 9 \\
\hline Total & 960 & 0 & 220 & 20 \\
\hline
\end{tabular}

Keterangan dari Tabel 1.

1. Tentukan Parameter Xi

Karena data pada Tabel 1 adalah data historis berjumlah ganjil, maka bernilai penuh.

2. Tentukan Parameter XiKuadrat

Setelah menentukan $X$ maka langkah selanjutnya dengan menentukan nilai XiKuadrat dengan cara mengkuadratkan nilai $\mathrm{X}$ yang sudah ditentukan tadi.

3. Tentukan nilai XiYi.

Cara mengalikan jumlah penjualan dari data yang bersangkutan (Yi), dengan data parameter $\mathrm{X}$.

4. Perhitungan untuk mencari minggu ketiga dengan nilai konstanta (a) dan parameter (b) adalah $: \mathrm{a}=\Sigma \mathrm{Y} / \mathrm{N}$ dan $\mathrm{b}=\Sigma \mathrm{XY} / \Sigma \mathrm{X} 2$

$$
\begin{aligned}
& a=960 / 4=240 \\
& b=220 / 20=11
\end{aligned}
$$

$$
\begin{aligned}
& \text { sehingga persamaannya adalah : } \\
& \begin{aligned}
& \mathrm{Y}=240+11(5) \quad \mathrm{Y}=240+11(7) \\
&=295 \\
&
\end{aligned}
\end{aligned}
$$

Maka, minggu pertama dan kedua bulan Februari 2017 adalah 295 pcs dan 317 pcs Tolak Angin.

5. Perhitungan Tingkat kesalahan.

Cara mengghitung ini cukup mudah yaitu dengan rumus $\mathrm{Xi} / \Sigma \mathrm{Y}$ (Y-Perkiraan)

Perkiraan ini saat diisi 80.

Tingkat Kesalahan : 4/960 (295-300) $=0,02$

$$
\text { : 4/960 (317-300) }=0,07
$$

Maka, tingkat kesalahan yaitu 0,02\% untuk minggu pertama Febuari dan 0,07\% untuk minggu kedua Februari.

\section{KESIMPULAN DAN SARAN \\ 6.1 Kesimpulan}

Dengan adanya pengembangan sistem perkiraan penjualan obat pada Apotek Demak Farma Jaya ini telah berhasil membantu dan 
mempermudah dalam pembuatan laporan untuk perkiraan penjualan yang akan datang.

Berikut ini beberapa kesimpulan mengenai penelitian ini :

1. Pihak Apotek Demak Farma Jaya sudah dapat melakukan pembuatan laporan untuk peramalan penjualan Obat dengan efektif dan efesien. Adanya program untuk peramalan penjualan Obat ini, diharapkan nantinya pihak Apotek Demak Farma Jaya sudah dapat merencanakan anggaran yang akan dibuat.

2. Pihak pemilik apotek dapat mengetahui secara langsung laporan terhadap perkiraan penjualan obat secara langsung, karena pada program yang dibuat pihak pemilik apotek dapat mengakses program secara langsung untuk melihat laporan perkiraan penjualan obat yang ada.

\subsection{Saran}

Berdasarkan kesimpulan-kesimpulan yang telah dikemukakan, dapat diajukan beberapa saran untuk pengembangan lebih lanjut antara lain:

1. Penambahan fitur perhitungan pada perkiraan penjualan yang bersifat lebih dinamis, dan otomatis sesuai dengan jangka waktu yang diinginkan.

2. Sistem ini sebaiknya dapat dikembangkan untuk perangkat android.

3. Sebaiknya sistem keamanan web dapat lebih baik lagi.

4. Tampilan webnya sebaiknya lebih user friendly.

\section{DAFTAR PUSTAKA}

Kadir, Abdul. 2009. Mudah Mempelajari Database MySQL. Yogyakarta: Penerbit Andi.

Nafirin, M. 2000. Penganggaran Perusahaan. Edisi Pertama. Salemba Empat. Jakarta.

Pamungkas, DP. 2016. Implementasi Metode Least Square untuk Prediksi Penjualan Tahu Pong. Jurnal Ilmiah NERO Vol. 2, No. 2.

Simamora, H. 2000. Basis Pengambilan Keputusan Bisnis. Salemba Empat. Jakarta.

Zuhriyanto, I. 2016. Analisis Rentet Waktu pada Data Pendonor dan Kebutuhan Darah Menggunakan Algoritma Linear Regression Dan Least Square. http://digilib.uin-

suka.ac.id/21310/2/12651049_BAB-

I_IV-atau-V_DAFTAR-PUSTAKA.pdf. 